\title{
Learning from Opening Data in the Context of E-Governance : Finland, with Special Reference to Government Location Data
}

\section{Ahonen, Pertti Pellervo}

Palgrave Macmillan

2018-01-01

Ahonen, P P 2018 , Learning from Opening Data in the Context of E-Governance : Finland, with Special Reference to Government Location Data . in L Alcalde Muñoz \& M P Rodríguez Bolívar (eds), International E-Government Development : Policy, Implementation and Best Practice . 1 edn , 11 , Palgrave Macmillan , Cham , pp. 271-290 . https://doi.org/10.1007/978-3-319-63284-1_11

http://hdl.handle.net/10138/310979

https://doi.org/10.1007/978-3-319-63284-1_11

unspecified

acceptedVersion

Downloaded from Helda, University of Helsinki institutional repository.

This is an electronic reprint of the original article.

This reprint may differ from the original in pagination and typographic detail.

Please cite the original version. 


\section{Learning from Opening DateData in the Context of E-GovernmentGovernance: Finland, with Special Reference to Governments'Government Location Data}

PerttiAhonen 1MEmailpertti.ahonen@helsinki.fi

\section{Pertti Ahonen}

is Professor of Political Science at the University of Helsinki. In 2015-2017 he led the research project Digital Humanities of Public Policy Formation, funded by the Kone Foundation of Finland. He has had recent articles in Sage Open, Big Data \& Society, Annals of Public and Cooperative Economics, Evaluation, and International Journal of Critical Accounting.

1Faculty of the Social SciencesUniversity of HelsinkiHelsinkiFinland

\section{A01} Abstract

The abstract is published online only. If you did not include a short abstract for the online version when you submitted the manuscript, the first paragraph or the first 10 lines of the chapter will be displayed here. If possible, please provide us with an informative abstract.

The purpose of this chapter is to construct a framework to examine change in e-governance, apply this framework in a one-country case study on opening government location data, and draw conclusions. The conceptual framework is comprised of four dimensions: influential historical, social and political mechanisms; the diffusion of innovations; stages of e-governance development; and facilitators of change. The research material is comprised of documents and interviews. According to the results, the will for e-governance change must increaseaccumulate in government and elsewhere, e-governance change has to be legitimated with accounts of its benefits, the costs of the change have to be accounted for, and organizational and individual facilitators may be needed. Conclusions are drawn for future research and those concerning e-governance practice in developed and developing countries. 11.1 .

\section{Introduction}

In this article "e-governance" refers to institutional arrangements and eertain activities within the bounds of these arrangements, such as analysinganalyzing, planning, deciding, organizing, implementing, managing, controlling, communicating, cooperating, and collaborating with the mediation of information and communication technologies (ICTs) (Milakovich 2012). The actors may be comprised of public governments, supra- and multi-national organizations, businesses, non-profit private organizations, and individual citizens, clients, or customers. It is possible to subdivide e-governance further, for instance, into e-government, e-democracy, ebusiness, e-commerce, e-management, and so on, and into components in which priority lies with individuals, institutional sectors, institutional structures, data, or decision-making (Veljković et al. 2014). 
The purpose of this chapter is to adopt and modify conceptual elements to construct a framework to examine e-governance and its change, to try this framework out in a one-country case study on the opening of governmentatgovernment location data, and draw conclusions from the results. The research purpose is general, whereas the empirical focus is delimited in order to examine actual actions by actual actors and the results of these actions, rather than generalities or official plans. The ambiguity of e-governance notions became evident during the research process. For instance, in the Finnish language and in this chapter, the empirical subject matter examined is comprised of paikkatieto or literally "location data" instead of "spatial data" or "geodata", for instance.

In order to be open, data must be primary, complete, timely, accessible, capable of machine processing, offered without discrimination towards the users, unbound to any proprietary data format, available under an open licencelicense, and accompanied with possibilities to review the depth and extent of the openness (Kitchin 2014, 49-66; OpenGovData 2016). More specific requirements have been outlined for " open data ecosystems

"with "infomediaries" that process the opened data, the formats for data packaging, and the availability of source code in open data repositories (Zuiderwijk et al. 2014). "Open data" may extend towards "open information" and "open knowledge" by means of linked data accessible by means of semantic queries concerning the data contents (Berners-Lee 2007; MF 2015a, b).

\section{AO2}

Despite appearances, the scope of e-governance in the open data domain is often confined to aspects of e-government only. This is also true of widespread global indexes of open data performance. Therefore

Finland

's comparatively good record (see the OUR open data index in OECD

2015, 201-203; GODI 2016; ODB 2016) says as little about actual open data performance in this country as it does in other countries.

Systematic generation of location data started in

Finland

during the period that

Finland

was part of Sweden, whose government launched systematic land surveying in the seventeenth century. After

Finland

was separated from Sweden in 1809, a national land survey administration was established in the autonomous Finnish grand duchy of the Russian empire. The present-day Finnish government agency, the National Land Survey, and its predecessor agencies since 1809 have been situated in the administration sector of a specific ministry or equivalent organization, meaning today the Ministry of Agriculture and Forestry. With global influences and national interpretations interacting, opening data in 


\section{Finland}

has not been without contradictions. Instead of an e-governance emphasis upon opening data irrespective of ownership, the e-government emphasis has predominated. The priorities have been on the unilateral opening of government data for domestic and international users motivated by generating societal benefits. However, emulation of international models rather than ideology (see, e.g., Bates 2014) has been the driver of developments in the Finnish case. Systematic Finnish e-government policies of opening location data started in the early 2010s at the same time as other open data policies. The opening of location data has primarily provided for web access to maps for domestic and international individuals and corporate users on condition of user registration (Maanmittauslaitos 2015; RI 2015, 2016.)

Representing multi-disciplinary political and social research rather than any confined discipline (see, e.g., Bannister and Connolly 2015), a conceptual framework is elaborated in Sect. 11.2. In the subsequent sections (Sects. 11.3 to 11.5), working hypotheses are proposed, and the research methodology is introduced. Next, the empirical results are presented in three major sections (Secs. 11.6 to 11.8), and in the final section (Sect. 11.9) conclusions and implications for practice and future research are drawn.

\section{2}

\section{Theory and Working Hypotheses}

\subsection{1.}

\section{Theory}

Like e-governance in general, policies on opening data have widely diffused globally. However, decisions concerning the opening of data may not take place in the same way in all countries nor lead to similar results everywhere. In this chapter an effort is made to explain the opening of data with reference to contributing influences and preventing obstacles. This article shares the neo-institutional idea first elaborated by Meyer and Rowan (1977) that institutions - including those influencing the opening of data-may not be merely rational tools to ensure performance, but may also have characteristics of political and social legitimation. This indicates examination of "e-governance", "e-government" and "open data" with attention to the possibility that the mere indication of the ends and the means to these ends may not exhaust the "words" uttered to deliver the "things" announced, but legitimatory language may be employed in addition. Neo-institutional research has also pointed out that not every policy-making cycle smoothly advances from initiation to implementation and ultimate results (Brunsson 2009), but may be incomplete, and many of the stages of policy-making processes may be coupled with each other in a loose rather than tight way. Interestingly, these imperfections have not gone unnoticed in the Open Budget Data (2016)Open data barometer (ODB 2016) ranking of achieved data openness.

\section{$\mathrm{AO3}$ A04}

It is also relevant to refer to the work of Tilly and Tarrow (2012) on "contentious agency", which grounds the actions of agents that try to utilize existing opportunities to generate change that would not otherwise occur. As a related development within neo-institutional research 
proper, Meyer and Hammerschmid (2006) have offered evidence that successful persuasion pursued by actors skillfully wielding their agency may effectively contribute to fundamental institutional change.

\section{$\mathbf{A 0 5}$}

For quite a while neo-institutional research, first arising in the late 1970s, was weak in addressing questions of fundamental institutional change. The above emphasis upon the agency of actors helps approach such institutional change properly. However, change does not imply that everything necessarily changes. New institutional elements, first diffused from the outside into a new context, are commonly modified rather than applied as such, and are sedimented amongst earlier elements. The ultimate results of institutionalization and re-institutionalization may represent heterogeneity despite common tendencies towards isomorphism of structures and etherother institutional elements (Lee and Strang 2006; for an application, see Lee et al. 2011). This type of neo-institutional research is well in accordance with e-governance research examining developments in stages (Kalampokis et al. 2011; Heimstädt et al. 2014). The above considerations indicate the importance of historically, politically, and socially specific contextual mechanisms that enable or constrain change, and demarcate opportunities for actors to generate change (Blatter and Haverland 2012). This depends on the competence of these actors tototo utilize the available opportunities for change until change actually takes place. Zuiderwijk and Janssenet al. (2014) credibly argue that despite the proliferation of open data policies, there has been a dearth of widely different frameworks to examine these policies. While recognizing the value of their conceptual framework, for the purposes of chapter article a different framework has to be applied.

Given the emphasis upon historical, political, and social contextual characteristics of institutionalization and institutional change, "empirical generalizations" presented as valid over all empirical cases and satisfying statistical criteria will not be drawn in this chapter as they cannot. Insofar as generalizations will be drawn, they represent "possibilistic generalizations" (Blatter and Haverland 2012) from the initial case to other cases in other contexts, after necessary contextual adjustments have been made to the assumptions concerning the mechanisms examined in the initial study.

\subsection{2.}

\section{Working Hypotheses}

Four working hypotheses are formulated on conditions for and obstacles to opening data to guide the study. These working hypotheses are formulated in a more general way than putting the focus upon opening data in order to make the hypotheses potentially relevant in later other e-governance research. These hypotheses can be spelled out as follows: 1 .

Sufficient political or other will must accumulate and possibly be expressed in general or more specific programmes or plans including blueprints for actual implementation.

2.

Benefits to society and other wide-reaching impacts must be legitimately accounted for. 3. 
The cost incurred must be calculated and included in relevant plans and accounts. 4.

"Infomediaries" and other facilitators, from organizations to individuals to analogies to social movements for change, may play important roles.

\section{A06}

\section{3 .}

\section{Methodology}

The research material is comprised of documents and results of semi-structured interviews. Because the opening of data is comprised of processes that have spread only relatively recently, many documents available on the web could be utilized. Six people were interviewed in 2015 and three more in 2016 (Appendix 1). In the interviews a specific series of questions were used (Appendix 2), and at the beginning of each interview the interviewee was told that his or her identity would not be revealed. Following good practice for qualitative empirical research, data collection was continued until saturation was indicated by the surfacing of themes and details that had been acquired in earlier data collection. Saturation also represents data triangulation in this study (Fusch and Ness 2015).

\section{A07}

Valuable feedback was received on conference papers delivered in the Permanent Study Group (PSG) on e-Government in the 2015 and 2016 conferences of the European Group of Public Administration (EGPA). Anonymous reviewers for this book and the editors of the book also contributed with suggestions for revision.

\section{4.}

\section{Overcoming Institutional Obstacles to Opening Government Data}

It is a common

complaint that many governments are comprised of "stovepipes" or "silos" of functionally specialized domains that are "joined up" deficiently (see, e.g.,

OECD

2010; Uusikylä 2013). Insofar as digitalization does not make the stovepipes and silos disappear (see Brown et al. 2014), these formations comprise some of the historically, politically, and socially specific mechanisms that either increase or decrease actors' opportunities to influence e-governance developments.

Finland

adheres to entrenched Nordic traditions of government openness and transparency

, with their earliest roots in eighteenth-century Sweden, prescribing that government documents shall be public except for those documents that are explicitly classified or not yet public at the current stage of their preparation (Erkkilä 2012). Analogous principles apply to electronic public documents. The 2008-2011 Finnish government led by PM Matti Vanhanen of the Centre party had considered removing some of the fees imposed for data collected by 
government agencies. The 2010-2011 successor government led by PM Mari Kiviniemi from the same party made a decision-in-principle on 3 March 2011 on opening government data. However, the government of PM Jyrki Katainen, a Conservative, nominated on 22 June 2011, was the first government to make the opening of data a point in its political programme (Katainen 2011, 86, official English translation):

Information resources produced using public funding will be opened up for public and corporate access. The goal is to make digital data materials managed by the public sector available to citizens, companies, enterprises and organisations, authorities, and for research and education purposes in an easily reusable format via information networks.

The opening of Finnish governmental location data became a suspense story during 2011 (RI 2015, 2016). The Ministry of Agriculture and Forestry had agreed with its subordinate agency, the National Land Survey, that customer fees be moderated to advance the opening of data. However, the Ministry of Finance, preparing the decisions taken by the statutory Ministerial Committee on Finance (chaired by the PM and other ministers in its membership), opposed the revision. Seeing that the opening of location data might fail, during the regular MPs' questioning hour to the government ministers, MP Oras Tynkkynen of the Green League (at that time a member of the government coalition) asked the Finance Minister, Jutta Urpilainen of the SDP, if her ministry indeed opposed the implementation of the government programme on opening the location data of the National Land Survey. The minister, who had been informed that the question would be raised, smoothly replied that the issue would be taken care of.

The Ministerial Committee on Finance decided against the opinion of the Ministry of Finance and, consequently, legislation enabling the National Land Survey to open location data was passed at the end of 2011. Finance Minister Urpilainen had thus agreed with the proposal and the government programme rather than with the expert civil servants of her own ministry and their ethos of austerity. However, the fact that the National Land Survey had promised to absorb the cost of opening its location data (1.5 million euros, or 10 per cent of the annual production cost of the data) without compensation from the government budget, possibly also facilitated resolving this issue.

In 2013-2014 the Katainen government and in 2014-2015 the successor government, headed by PM Alexander Stubb of the same party as Katainen, implemented a specific government programme on opening data (MF 2015a, b). With the 2012 opening of the National Land Survey location data as the starting point, during the programme implementation steps were taken to open weather data, climate data, maritime data, and climate model data. The programme foresaw continuation with the opening of several other types of data. During the programme implementation, a national open data portal was launched in September 2014 (Open Data

Finland

2015). Developing an "open location data ecosystem" comprised a specific pilot project within the programme in 2014-2015. By 2015, more than 1400 government datasets had been opened, and by 2020, all government data that can be opened in the first place should be open. 
According to the Finnish government programme nominated on 29 May 2015, headed by PM Juha Sipilä of the Centre party, the opening of government data should continue as an aspect of the government's wider emphasis upon the digitalization of government, governance, and society. The digitalization of government is supposed to enable a considerable part of the cost savings to which the government aims, or up to one half, the other mostly comprised of budgetary cutbacks (RI 2015, 2016). The Sipilä government programme states (Sipilä 2015, 28; official English translation; see also MF 2015c):

Innovation and service platforms will be promoted in sectors where the public administration plays a role in terms of the functioning of the markets. Such sectors include mobility as a service, health care, learning and the Industrial Internet. The introduction of new technologies, digitalisation and new business concepts will be promoted by legislative means. With the help of open data and the better use of data resources, favourable conditions will be provided for new business ideas.

We can envisage countries in which full coordination prevails in e-governance developments in the federal or national government and in local government. However, the Finnish municipalities both have a constitutional political autonomy and comprise an influential political interest sector that does not necessarily yield to government demands. This means that in the Finnish case, local government open data developments are pronouncedly separate from those in national government. Several Finnish municipalities have been opening their data, most extensively in the Helsinki metropolitan region. Relevant institutionalization includes, for instance, the open data net service Helsinki Region Infoshare of the local cities, and the digital services development company Forum Virium Helsinki Ltd. owned by the city of Helsinki but with important public-private-partnership characteristics (Jaakkola et al. 2015).

11.5 .

\section{Legitimating the Opening of Location Data}

Institutional elements introduced in

Finland

to open data have global rather than domestic origins. However, these elements typically have not been transferred from their original contexts to the Finnish context as such, but have been modified.

The EU legislation on infrastructures for spatial information apparently represents substantially more than general legitimation for member state measures concerning location data (European Commission 2015). However, the fact that this legislation consists of EU Directive 2007/2, best known under the acronym INSPIRE

, gives the member states leeway in implementing it in their national legislation (Directive 2007). Moreover, the Commission has passed a good number of implementing regulations concerning the

INSPIRE

directive, adding further complexity. The

INSPIRE 
directive also addresses no fewer than 34 spatial data themes, which hardly promotes simplicity, either.

Finland

implemented the

INSPIRE

directive by passing an Act of Parliament on location data infrastructure (Laki

paikkatietoinfrastruktuurista 2009), and participates in the EU network set up to support and follow up the national implementation experiences of the directive (EU 2016). According to an evaluation, the

\section{INSPIRE}

directive has by and large served its purpose despite certain implementation problems (EC 2016).

From among the international organizations in which

Finland

is a member, the

\section{OECD}

sponsors measures to open government data and to follow up these measures (Ubaldi 2013; OECD

2015). Looser international cooperation also exists, such as the

Open Government Partnership (OGP)

comprising 65 countries in mid-2015,

Finland

joining in April 2013 (RI 2015, 2016).

References to other countries and organizations in these countries have been common sources of ex post rather than ex ante legitimation of opening government data in

Finland

(RI 2015, 2016). These references have included, for instance, the open data policies of the British 2010-2015 coalition government, the Obama administration in the United States since 2008, the Spanish opening of the location data of the General Directorate of the Cadastre, and opening the location data of Britain's Ordnance Survey and the Dutch Cadastre, Land Registry and Mapping Agency.

Calculations of the costs of opening governmental location data in

Finland

have also served ex post legitimation purposes rather than ex ante financial planning (RI 2015, 2016). In the ex post legitimation indicated, arguments have been common concerning the public interest, the societal benefits, and the importance of free-of-charge collective goods funded by taxpayers.

The first major study on the effects of the opening of the National Land Survey data in 2012 (Ahonen-Rainio et al. 2014) built on a questionnaire survey to examine the uses of location data and the benefits of these data to their users. The economic effects were assessed in a qualitative way without monetizing these effects. According to the results, companies had 
drawn benefits from open location data insofar as these data had enabled new services and products, better operative efficiency, or improved domestic or international competitive advantage. However, the opening had failed to give rise to substantial new markets because of the limited demand for Finnish location data. The Finnish Ministry of Finance also commissioned a study on the impacts of open data from an outsourced provider, including economic impacts (Koski 2015), but the study was only a preliminary rather than a true empirical account of the economic impacts.

Concerning the opening of governmental location data in

Finland

, business interests have hardly directly influenced the opening decisions. The foremost paying customer for the National Land Survey open location data had been the Finnish subsidiary of the American company ESRI of Redlands, California, which was practically unknown to the Finnish public. Finns have had few strong opinions on opening government data, as they characteristically see only the end products such as printed maps or newer digital location data applications, or utilize location data acquired by companies that resell these data once built into motor vehicle navigators or personal navigators, or made available in free applications that public transportation providers supply. However, issues have been raised, asking if opening data is always value-neutral and beneficial to everybody (Kitchin 2014, 62-64; RI 2015, 2016). In the Finnish case, rather than common citizens, smaller developer communities including those with linkages to startup companies and principled activists for opening government data have played roles as representatives of the beneficiaries (RI 2015, 2016).

11.6.

\section{Accounting for the Costs of Opening Location Data}

While the benefits weigh heavily in the scales in the ex ante and ex post assessment of opening government data, so to do the costs (RI 2015, 2016). Opening location data in 2012 represented a modest annual reduction of 1.5 million euros in operational revenue to government generated at the Finnish National Land Survey, or about 10 per cent of the cost of generating these data. Moreover, the increased demand for the data after their opening - with 50 times more users and 50 times greater data demand-incurred costs for the National Land Survey. However, as indicated (Sect. 11.4), the fact that the National Land Survey was ready to absorb the costs of opening its location data without compensation from the annual government budget probably facilitated its ultimate opening.

Gaps have been identified in the Finnish location data opening procedures (RI 2015, 2016). The data have been opened for citizens, companies, local governments, and other users groups, but not within the Finnish national government administration itself so that different authorities could tap a common topographical database. Many functions exist in which location data are not utilized, such as awarding permits for measures influencing the environment or fire and rescue services, but instead traditional address data are used (RI 2015, 2016). 11.7 . 


\section{Opening Government Location Data in Stages}

Some of the roots of opening government data in

Finland

derive from the historical Nordic principles and practices of openness and transparency

in the dealings of government authorities. More recent roots grow from the Finnish political interest in creating a world-class information society since the 1990s, and from the diffusion of global institutional models and scripts of opening governmental data into this country.

In

Finland

in the first decade of the second millennium, the legal norms applied to numerous government services frequently posed obstacles to the use of government-generated data whichthat satisfy socio-economic efficiency. The "suspense story" told in Sect. 11.4 above indicates contradictions between the Ministry of Finance as the guardian of government austerity on the one hand and a government with a clause in its political programme on opening government data.

The examination in this chapter reveals certain institutional and other obstacles to opening data (RI 2015, 2016; see also Barry and Bannister 2014; Dulong de Rosnay and Janssen 2014). Frequently, despite the fact that data could in principle be opened and the opening decisions receive substantial political support, a single legal norm may prevent the opening or limit its scope. Norms restricting the opening have been issued to protect the privacy of citizens, business secrets, copyright, and national security. According to one of the interviewees (RI 2015, 2016, my translation), the "protected interests of one per cent of the population may prevent opening government data for the benefit for the remaining ninety-nine per cent". In the specific case of location data in

Finland

, the protection of the privacy of ownership has constrained the opening of real estate location data, which is in certain respects more detailed than other location data. Moreover, sales of real estate data comprise a revenue source for many Finnish local governments, of which some have not been willing supporters for the more extensive opening of location data.

What has been opened may reveal better what is still closed. We might expect that the post office codes, related to all addresses in

Finland

, would have been made available given the importance and widespread utilization of these codes as a specific type of location data. However, the postal services are run by a joint-stock company that despite its national government ownership operates like a private enterprise (and in some respects even more so), and the opening of the post office code data has been lagging (RI 2015, 2016).

11.8 .

Facilitators in Opening Government Data: Organizations, Events, Networks, and Individuals 
The Finnish government has three times, in 2010, 2013 and 2016, nominated a consultative commission on location data and the national location data infrastructure (Paikkatietoasioiden neuvottelukunta) for a three-year term. In 2014, this commission published a national strategy on location data (MAF 2014). A more informal institution, the Location Data Network, connects 120 organizations and 350 individual members from the public, commercial, and private non-profit sectors. The Finnish National Land Survey also actively promotes the elaboration of its user interface by means of organizing the annual paikkatietomarkkinat (the "location data marketplace").

In its turn, ProGIS is a non-profit organization promoting the utilization of geographic information (GI) and geographic information systems (GIS) for the benefit of Finnish society in the capacity of a link between producers and users of GI and vendors of GI services and software. Moreover, commercial providers of location data services, infrastructures and technology have established the Finnish Location Information Cluster (FLIC) of about 30 members (FLIC 2016). The National Land Survey, ProGIS, and FLIC cooperate in organizing the annual location data marketplace.

\section{$\underline{\mathrm{A} 08}$}

Individual experts have been invited to

Finland

in connection with the opening of the location data of the Finnish National Land Survey (RI 2015, 2016). Peter ter Haar of the British Ordnance Survey visited the annual "location data marketplace" of the Finnish National Land Survey on 2-3 November 2011, explaining the British process of opening location data. The following year, Ton Zijlstra from the Netherlands visited the Apps4Finland competition and demonstrated the Dutch case of opening governmental location data.

Besides the Ministry of Agriculture and Forestry and the Ministry of Finance, the Ministry of Transport and Communications has also been active in matters related to opening governmental data, and has commissioned a guidebook on the subject (Poikola et al. 2010). The first author, Antti Poikola widely known as "Jogi" (Yogi) Poikola, later became the chair of Open Knowledge

Finland

in the capacity of a social activist promoting the case of opening government data. From among civil servants, the catalytic role of Antti Rainio must be mentioned (RI 2015, 2016). Rainio, moving between functions in the Finnish National Land Survey and the Ministry of Finance, played key roles in catalysing the opening of the location data of the Finnish National Land Survey in 2011-2012. A pioneer in opening location data since the 1980s and the civil servant head responsible for preparing

Finland

's information society strategy in the late 1990s, Rainio was a member of the 2010-2011 working group of the Ministry of Transport and Communications that prepared the 2011 Finnish government decision-in-principle on opening government data. 


\title{
Conclusions and Implications for Future Research and Practice
}

\author{
11.9.1.
}

Conclusions

Driven by four working hypotheses, in this chapter the e-governance and e-government case for opening governmental location data in

Finland

has been examined. In respect of the first working hypothesis, accumulation of political will definitely affect the opening of location data accumulated by the Finnish National Land Survey. A crucial turning point was the decision-in-principle on opening data taken by the 2010-2011 government led by Mari Kiviniemi of the Center party. The participation of a civil servant, Antti Rainio, moving between the National Land Survey and the Ministry of Finance in the preparatory group of the decision-in-principle, functioned as an important catalyst to open governmental location data. Opening government data in general was first explicitly written into the political programme of the subsequent 2011-2014 government led by Jyrki Katainen of the Conservatives, and reference to this programme in late 2011 clearly contributed to the opening decision concerning governmental location data at the end of the same year.

Referring to the second working hypothesis, the broader socio-economic framing was also found to be important. Many arguments in favour of opening government data have been presented as ex post legitimation rather than as ex ante motivation for opening governmental data in

Finland

. And as concerns the third working hypothesis, the decision to open the location data of the Finnish National Land Survey hinged on overcoming the resistance of the Ministry of Finance despite the fact that the fiscal cost of opening was negligible.

The fourth working hypothesis directed attention towards organizations, regular or extraordinary events, networks, and individuals with roles in catalysing the opening of government data. Nothing less than a short-lived, single-purpose, social movement arose in support of the opening of governmental location data.

11.9.2.

\section{Implications for Future Research}

Broadly speaking, this chapter implies the need for future studies on the same aspects as those emphasized by the four working hypotheses: the will for change, accounting for benefits to society and other wide-reaching impacts, accounting for economic costs, and the facilitation of change by change agents. As indicated in Sect. 11.2.1. above, using this study in future research requires "possibilistic generalizations" (Blatter and Haverland 2012) from the case examined to other cases with suitable modifications to the contextual conditions that prevailed in the initial study object. In the other cases, the subject matter may be different, and different mechanisms may influence this subject matter. The more the subject matter diverges from 
opening governmental location data and the more different the contextual conditions are from those in

Finland

, the heavier the modifications must be. Some of these modifications become necessary insofar as e-governance in developing countries is examined, in particular.

During the research process the author became aware of possible blind spots in e-governance research. Possibly too many researchers of e-governance, e-government, opening data, and opening governmental location data have repeated "grand narratives" of technological advancement, human improvement, and economic growth by means of technology, and almost unlimited progress. However, technology also has its risky and contingent downside, including the availability of networked ICT not only for honest businesses, ethically behaving governments, and citizens of integrity, but businesses that are fraudulent or worse, government authorities overstepping their mark, groups envisaging violent attacks, and hostile foreign powers. Keeping to location data, these data can certainly be utilized for improving the supply of basic necessities and other commodities, societal equality, and the quality of individuals' lives. However, these data can alternatively be used for negative purposes. This implies that egovernance research should by no means consign to silence the fragility of corporate social responsibility, the vulnerability of political freedom and other citizens' rights, and the pressure on local, national, and global peace.

\subsection{3.}

\section{Implications for Practice in Developed and Less Developed Countries}

To consider the practical lessons in countries with different levels of development we need to take into consideration the specific situation of each individual country (see also Dey et al. 2016). The accumulation of political will may, for example, take place in a developing country with only weak support from democratic decision-making majorities and with lower acceptance of political opposition groups than in many highly developed countries. In such circumstances, accomplishing e-governance changes rather than official declarations may be particularly difficult. These difficulties are aggravated insofar as the institutions of implementation suffer from weakness, fragility, or lack of integrity. Highly developed countries may have a substantial tolerance towards failure in e-governance policies, whereas developing countries may not be able to afford similar let alone higher failure rates. The adverse effects of gaps between official policies and actual implementation rates, and actual policy impacts, may therefore be more serious in developing than in highly developed countries.

However, lower levels of development also offer certain e-governance advantages. One of these is the latecomer's advantage, enabling learning from the mistakes of early adopters (Nugroho et al. 2015). Examples also exist of the particularly favourable effects of ICTs in developing countries, compensating for the lesser development of infrastructures that have been taken for granted in highly developed countries for decades. In developing countries, for instance, ICTs may compensate for the relative underdevelopment of fixed telecommunication lines, land transportation, and banking and finance (van der Boor et al. 2014). Last but not 
least, the introduction of innovations in developing countries may support the elaboration of stronger social networks of the civil society and better political inclusion (see, e.g., Holden and Van Klyton 2016), although risks are also involved, including the expansion of political and social dissatisfaction with movements that lack peaceful outlets to articulate their demands.

\section{Bibliography}

Ahonen-Rainio, P., Mäkelä, J., \& Virrantaus, K.. 2014. Menetelmä avoimen maastotiedon vaikuttavuuden arvioimiseksi. Publication on a method to assess the effectiveness of open terrain data, in Finnish. Espoo: Aalto University.

Bannister, F., \& Connolly, R. (2015). The great theory hunt: Does e-Government really have a problem? Government Information Quarterly, 32, 1-11.

Barry, E., \& Bannister, F. (2014). Barriers to open data release: A view from the top. Information Polity, 19, 129-152.

Bates, J. (2014). The strategic importance of information policy for the contemporary neoliberal state: The case of open government data in the United Kingdom. Government Information Quarterly, 31, 388-395.

Berners-Lee, T. (2007). Linked data. Retrieved July 5, 2015, from http://www.w3.org/DesignIssues/LinkedData.html

Blatter, J., \& Haverland, M. (2012). Designing case studies: Explanatory approaches in small$N$ research. Basingstoke: Palgrave Macmillan.

van der Boor, P., Oliveira, P., \& Veloso, F. (2014). Users as innovators in developing countries: The Global sources of innovation and diffusion in mobile banking services. Research Policy, 43, 1594-1607.

Brunsson, N. (2009). Reform as routine: Organizational change in the modern world. Oxford: Oxford University Press.

Dey, B., Sorour, K., \& Filieri, R. (Eds.). (2016). ICTs in developing countries. Berlin: Springer.

Directive. (2007). Directive 2007/2/EC of the European Parliament and of the Council of 14 March 2007 Establishing an Infrastructure for Spatial Information in the European Community (known under the acronym INSPIRE). Retrieved June 20, 2015,

from http://inspire.ec.europa.eu/inspire-legislation/26

Dulong de Rosnay, M., \& Janssen, K. (2014). Legal and institutional challenges for opening data across public sectors: Towards common policy solutions. Journal of Theoretical and Applied Electronic Commerce Research, 9, 1-14.

EC. (2016). Report from the Commission to the Council and the European Parliament on the implementation of Directive 2007/2/EC of March 2007 establishing an Infrastructure for Spatial Information in the European Community (INSPIRE) pursuant to article 23. Retrieved October 14, 2016, from http://inspire.ec.europa.eu/news/commissions-inspire-report-and-refitevaluation-published

Erkkilä, T. (2012). Government transparency: Impacts and unintended consequences.

Basingstoke: Palgrave Macmillan. 
EU. (2016). EU Share-PSI 2.0. 2016. Web pages of the network for innovation in European public sector innovation. Retrieved June 20, 2016, from https://www.w3.org/2013/share-psi/lg/ FLIC. (2016). The Finnish location information cluster. Retrieved July 15, 2015, from http://www.flic.fi

Fusch, P. I., \& Ness, L. R. (2015). Are we there yet? Data saturation in qualitative research. The Qualitative Report, 20, 1408-1416.

GODI. (2016). Global open data index. Retrieved July 2, 2016, from http://index.okfn.org/place/

Heimstädt, M., Saunderson, F., \& Heath, T. (2014). From toddler to teen: Growth of open data ecosystem. A longitudinal analysis of open data developments in the UK. Journal of eDemocracy, 6, 123-135.

Holden, K., \& Van Klyton, A. (2016). Exploring the tensions and incongruities of internet governance in Africa. Government Information Quarterly, 33. electronic preprint. Retrieved October 15, 2016, from doi: 10.106/j.giq.2016.08.00g.

INSPIRE. See Directive 2007.

Jaakkola, A., Kekkonen, H., Lahti, T., \& Manninen, A. (2015). Open data open cities:

Experiences from the Helsinki metropolitan area, case Helsinki region Infoshare www.hri.fi. Statistical Journal of the IOS, 31, 117-122.

Kalampokis, E., Tambouri, E., \& Tarabanis, K. (2011). Open government data: A stage model. In M. Janssen, H. J. Scholl, M. A. Wimmer, \& Y. H. Tan (Eds.), Electronic government (pp. 235-246). Heidelberg: Springer.

Katainen, J. 2011. Programme of Prime Minister Jyrki Katainen's government. Official English translation. Helsinki: Prime Minister's Office.

Kitchin, R. (2014). The data revolution: Big data, open data, data infrastructures \& their consequences. London: Sage.

Koski, H. (2015). The impact of open data. Helsinki: Ministry of Finance.

Laki paikkatietoinfrastruktuurista. (2009). Parliament act on location data infrastructure. 12 June 2009, no. 421. In Finnish.

Lee, C. K., \& Strang, D. (2006). The international diffusion of public-sector downsizing: Network emulation and theory-driven learning. International Organization, 60, 883-909. Lee, C., Chang, K., \& Berry, F. S. (2011). Testing the development and diffusion of eGovernment and e-Democracy. Public Administration Review, 71, 444-454.

Maanmittauslaitos. (2015). Digitaaliset tuotteet. Web pages of the National Land Survey, Finland, concerning its digital products. Retrieved April 11, 2015, from http://www.maanmittauslaitos.fi/aineistot-palvelut/ MAF. (2014). Kansallinen paikkatietostrategia 2016. The Finnish national location data strategy until 2016. Helsinki: Ministry of Agriculture and Forestry.

Meyer, R., \& Hammerschmid, G. (2006). Changing institutional logics and executive identities: A managerial challenge to public administration in Austria. American Behavioral Scientist, 49, 1000-1014. 
Meyer, J. W., \& Rowan, B. (1977). Institutionalized organizations: Formal structure as myth and ceremony. American Journal of Sociology, 83, 340-363.

MF. (2015a). Avoimen tiedon ohjelma. Open data program, in Finnish. Ministry of Finance. Retrieved April 11, 2015, from http://vm.fi/avointieto

MF. (2015b). Avoimesta datasta innovatiiviseen tiedon hyödyntämiseen: Avoimen tiedon ohjelman 2013-2015 loppuraportti. Final report of the Finnish open data program, in Finnish. Ministry of Finance. Retrieved April 11, 2015, from http://vm.fi/julkaisu?pubid=6902 MF. (2015c). Digitalisaatio. Web pages on digitalization. Retrieved July 12, 2015, from http://vm.fi/digitalisaatio

Milakovich, M. E. (2012). Digital governance: New technologies for improving public service and participation. New York: Routledge.

Nugroho, R. P., Zuiderwijk, A., \& Janssen, M. (2015). A comparison of national open data policies: Lessons learned. Transforming Government: People, Process and Policy, 9, 286-308. ODB. (2016). Open data barometer. Retrieved July 7, 2016,

from http://opendatabarometer.org/

OECD. (2010). Finland: Working together to sustain success. Paris: OECD.

OECD. (2015). Government at a glance. Paris: OECD.

Open Data Finland. (2015). Open data Finland. Finnish government open data portal.

Retrieved June 21, 2015, from https://www.opendata.fi/en

OpenGovData. (2016). The eight principles of open government data. Retrieved July 7, 2016, from http://opengovdata.org

Poikola, A., Kola, P., \& Hintikka, K. A. (2010). Public data - An introduction to opening information resources. Helsinki: Ministry of Transport and Communications.

RI. (2015). Research interviews for this study by the author, April to June 2015.

RI. (2016). Research interviews for this study by the author, June to July 2016.

Sipilä, J. (2015). Programme of Prime Minister Juha Sipilä's Government. Official English translation. Helsinki: Prime Minister's Office.

Tilly, C., \& Tarrow, S. (2012). Contentious politics (2 fully Rev. and updated ed.). Oxford: Oxford University Press.

Ubaldi, B. B. (2013). Open government data: Towards empirical analysis of open data initiatives. Paris: OECD.

Uusikylä, P. (2013). Transforming silo-steering into a performance governance system: The case of the Finnish Central Government. New Directions for Evaluation, 21, 33-43. Veljković, N., Bogdanović-Dinić, S., \& Stoimenov, L. (2014). Benchmarking open government: An open data perspective. Government Information Quarterly, 31, 278-290.

Zuiderwijk, A. M. G., Janssen, M. F. W. H. A., \& Davis, C. B. (2014). Innovation with open data: Essential elements of open data ecosystems. Information Polity, 19, 17-33.

Proof Review

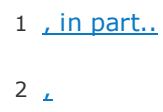



3 that
4 relevant..
5 widely di..
6 to
7 other ins..
8 Open data..
9 (European..
10 (see Brow..
11 et al.
12 Affiliati..
13 license
14 government
$15+$
16 analyzing
17 certain
18 those
19 accumulate
20 Governance
21 Government
22 Data 